\title{
Towards eGovernment Interoperability: Lithuania Case
}

\author{
Rimantas Gatautis and Elena Vitkauskaite
}

Kaunas University of Technology, Kaunas, Lithuania

\begin{abstract}
The interoperability problems have been faced by many countries governmental institutions at international, national and local levels. eGovernment Interoperability Frameworks act as the mechanisms that prescribe the prerequisites for one-stop, web-enabled e-Government Services and support their deployment in the vast number of public administration information systems.

The current paper analyzes eGovernment interoperability framework development preconditions in Lithuania, good practice experience in developing eGovernment interoperability frameworks at EU level (European Interoperability Framework) and national levels - UK, Germany and Greece. Comparing these frameworks by different criteria the key principles of Lithuanian eGovernment interoperability framework are indentified. The project for Lithuania eGovernment Interoperability framework development is supported by Ministry of Interior of the Republic of Lithuania and Lithuania State Science and Studies Foundation.
\end{abstract}

Keywords: Interoperability, eGovernment, Framework, Lithuania

\section{Introduction}

Information communication technology (ICT) adaptation in public administration processes are closely related to improvement of public sector efficiency and effectiveness. ICT adaptation commonly refers to as electronic government (eGovernment), which is described as seamless integration of computer-supported government services. In the beginning of 21st century citizens' expectations and new laws and regulations requires that information need only be given once and need to be reused by others create a huge need for interoperability among public and private organizations. All these organization comprise hundreds, thousands, or even more applications that need to communicate with each other.

Interoperability is not a new concept in the domain of computer systems. Interoperability of computer system is defined by IEEE as "the ability of two or more systems or components to exchange information and to use the information that has been exchanged" [10]. Electronic dictionaries define interoperability as "The ability of software and hardware on multiple machines from multiple vendors to communicate". For the purposes of this study, we define interoperability as: The ability of distinct systems to communicate and share semantically compatible information, perform compatible transactions, and interact in ways that support compatible business processes 6 to enable their users to perform desired tasks. [15] Although our definition of interoperability was derived from a technical perspective, it applies to all aspects of eGovernment, if "system" is interpreted broadly. Note that this broad definition implies that an IF is far more than just a list of recommended standards. From a purely technological perspective, interoperability concerns the ability of two or more ICT assets (hardware devices, communications devices or software components) to easily or automatically work together. However, business and government also require interoperability of processes, so that business processes or administrative services can link up easily through computing/ communications processes.

From the early days of eGovernment, interoperability was perceived as a critical challenge and enabler. Interoperability has a central role in eGovernment and as a result Copyright (c) 2010 Rimantas Gatautis and Elena Vitkauskaite. This is an open access article distributed under the Creative Commons Attribution License unported 3.0, which permits unrestricted use, distribution, and reproduction in any medium, provided that original work is properly cited. The article is a reprint from a 2009 article. Contact author: Rimantas Gatautis. E-mail: rgataut@ktu.lt 
significant work has been already conducted. Since 1991, interoperability has remained an important EU goal - especially in the eGovernment context. To take one particularly pertinent example, in June 2002 the eEurope 2005 Action Plan made the development of a European Interoperability Framework (EIF) a priority component of pan-European eGovernment strategy. [14]

By needing to reuse information Interoperability is an important issue for all types of government, including policy making, services delivery, law enforcement and crisis response. Police departments, health and safety departments, and first responders need to be able to communicate during wide-scale emergencies. In the past, agencies could not exchange information because they operated widely disparate hardware that was incompatible. With the advent of the Internet, a communication infrastructure has been created and with the rise of Service-Oriented Architectures (SOA) and web services as technology, the technology threshold for interoperability has been lowered. As more business and governmental systems can be accessed using web services, research emphasis is shifting to the coordination of web services invocations, thus from enhancing interoperability at the data exchange level to the business process level [21].

System complexity, multiplicity and diversity in the public sector is posing extreme challenges to common interoperability standards the eGovernment Interoperability Frameworks (eGIFs) pose as a cornerstone for the provision of one-stop, fully electronic services to businesses and citizens. Such interoperability frameworks aim at outlining the essential prerequisites for joined-up and web-enabled Pan-European e-Government Services (PEGS), covering their definition and deployment over thousands of front-office and back-office systems in an ever extending set of public administration organisations.

\section{2. eGovernment Interoperability in Lithuania}

The Lithuanian eGovernment strategy is laid down in the Position Paper on eGovernment adopted by the government on 31 December 2002. The ultimate goal is to improve transparency of the decision making process of the executive bodies of the Republic of Lithuania in order to deliver high quality public services efficiently and provide information to the public, businesses and institutions. For this purpose, possibilities offered by information technology are necessary.
In this context, the Information Society Development Committee established a working group on interoperability of the information systems of the State. One of the most important Lithuanian IT projects is the creation of system interaction capabilities through public administration institutions interoperability. [12]

Approximately 126 million Litas (36 million euro) of EU structural funds and national cofinancing aid for Lithuania's information society for the period 2004-2006 will be spent for projects related to electronic government. Tender "Electronic government and eServices" which aims to create possibilities for all citizens and businesses of Lithuania to use ICT for communication with public institutions and to modernize services of public sector includes projects subgroup "Interoperability". The goal of these projects is to achieve interoperability of the public sector information kept in public institutions' information systems, as far as it is permitted by legislation.

On the basis of the model created for electronic public services in October 2004, a pilot project "Development of portal functional and technical infrastructure and services" was started. After this project, public service "announcement of movement" and all related services will be transferred onto the Internet. Possibilities to implement other public services on the basis of "one-stop-shop" will be embodied. Software will ensure input of user data to the information systems of the Migration Department and the Resident's Register Centre and will ensure review of data in the Real Estate Register.

The functional scheme of the eGovernment portal (see Figure 1):

- The user inputs the system query for the service. There are three cases of identification in the information system - using an existing e-banking account (private and public sector used this for 2004 for tax declarations to the Tax Inspectorate information system 10 percent of residents), using PKI qualified (non-qualified) certificates or mobile electronic signature (using mobile phone).

- User queries are sent to a data centre providing the functions of the front office of the eGovernment portal.

- User queries are automatically (using defined bureaucratic procedures in the database) forwarded to the institutions (decision-makers). Data needed for the decision is sent to state institutions. The queries are forwarded directly to the responsible persons of the state institutions. 
- The procedures of the public services are described in the data center database. In some cases the chain of decision-making is connected to two or more state institutions or decisions of institutions are independent of each other.

- The platform of the data centre has a possibility to integrate with the back office of state institutions.

- The data centre stores and analyzes input/output data of state institutions', and observes the realization of public services, and sends appointments to state institutions' officers and decision makers.

- Decisions of decision makers (and/or queries of the civil servants) are signed with electronic signatures. Civil servants use electronic signatures from PKI infrastructure for closed groups.

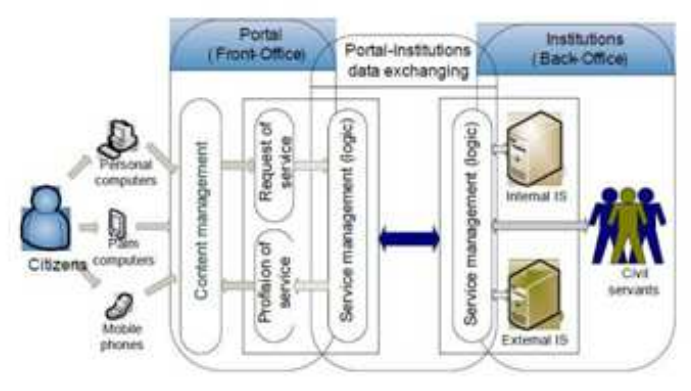

Fig. 1. Conceptual Model of the eGovernment Portal

Limitations of the present portal:

- There is no identification system of visitors implemented in this portal, without this system it is impossible to provide fully interactive electronic public services.

- The "one-stop-shop" principle is not realized. Users should only have to identify and authenticate themselves once to obtain any electronic public service independent of institution providing it.

- $\quad$ Electronic documents produced by civil servants now are doubled in paper and electronic form. It is impossible to ensure security and archiving of them for a defined period of time.

- It is difficult to manage newly appearing electronic public services and changes with already existing procedures.

- The bureaucratic procedures are unclear (can be also excessive) for a user that needs to know what institution provides what services.

- Complicated maintenance of the portal.
However, interoperability of information systems of state institutions is mentioned in various strategies. An electronic signature infrastructure was created and implemented. A project called "Creation of Interoperability of Public Administration Institutions' Information Systems" was begun in 2006. The purpose of the project is to create an interoperability framework of institutions and a portal with central identification. June 2008 new project was begun which aims to develop Lithuanian eGovernment Interoperability Framework in order to provide Lithuanian government with guidelines for dealing interoperability issues at national level. But at the moment an explicit strategy for interoperability does not exist.

\section{3. eGovernment Interoperability Frameworks in Europe}

Because eGovernment interoperability frameworks are still a relatively new concept, there are not yet many examples to choose from, and most of those that exist appear to be well known.

Nowadays, building an e-Government Interoperability Framework must oppose the tendency to "reinvent the wheel" and requires examination and extended review of related research and standardization efforts [5] in the EU, the UK, Germany, Greece and other EU countries (see Figure 2).

This paper present comparison of best practice in implementation of eGovernment interoperability frameworks according certain criteria in following countries:

- At European level, the European Interoperability Framework - EIF (Version 1.0) [8].

- e-Government Interoperability Framework [2] of United Kingdom.

- Germanys' Standards and Architectures for e-Government Applications (SAGA) Version 3.0. [12]

- Greece and its' new Greek eGovernment Service Provision and Interoperability Framework [18].

Despite being small, this sample provided a good mix of national and EU efforts. The specific rationales for our choices were as follows. The EU EIF was a given, since it provides an overarching set of interoperability criteria (the IDABC Architecture Guidelines provide a related architectural perspective). Most national interoperability frameworks refer to the EIF as well and strive for at least partial compliance with it. The UK's eGIF is one of the most mature (in the sense of having been around longest and having been through the most revisions) and 
complete of the national interoperability frameworks and is heavily referenced in other interoperability frameworks, making it a natural choice. Germanys' SAGA is second of most mature interoperability frameworks. Greece brings to the sample ambitious and most recent effort of so called second generation interoperability framework.

The following subsections present key observations about the sample interoperability frameworks that we analysed. The intent here is not to give exhaustive analyses, but rather to highlight and contrast the most salient features and aspects of these interoperability frameworks.

\section{European Interoperability Framework}

The EU's EIF and the supporting IDABC Architecture Guidelines are intended to address the interoperability of pan-European eGovernment services (PEGS).
Its scope includes A2A, A2C, and A2B (where "A" stands for "Administration", " $C$ " for "Citizens" and "B" for "Business").

The EIF identifies three types of PEGS interactions:

- Direct interaction between citizens or enterprises of one Member State with administrations of other Member States and/or institutions;

- The exchange of data between administrations of different Member States in order to resolve cases that citizens or enterprises may raise with the administration of their own country;

- The exchange of data between various EU institutions or agencies, or between an EU institution or agency and one or more administrations of Member States.

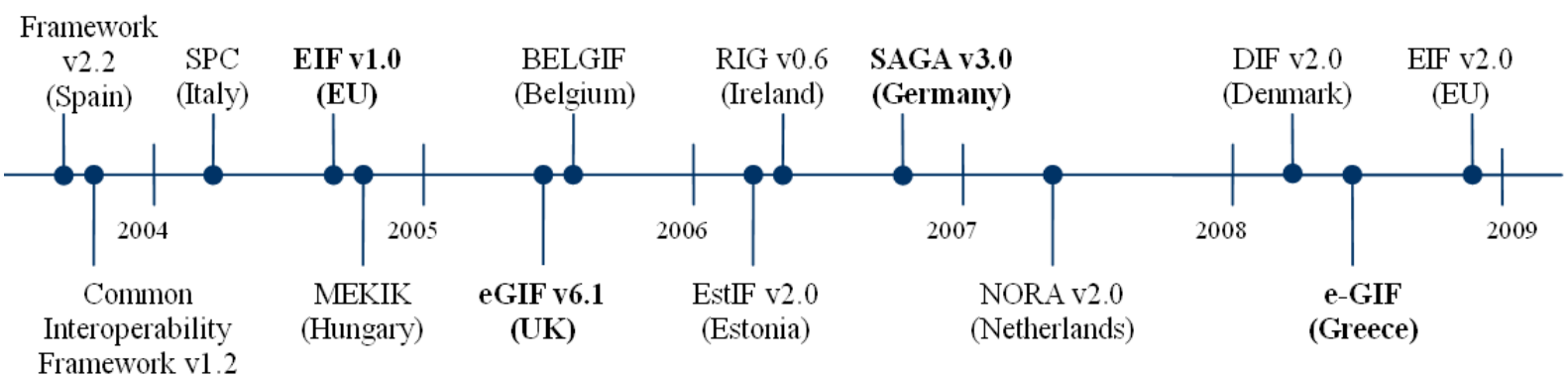

(France)

The EIF's recommendations are quite high level, whereas the related IDABC Architecture Guidelines are very low level (mentioning many specific standards such as PKI (Public Key Infrastructure), XML (Extensible Mark-up Language), SOAP, WSDL (Web Services Description Language), etc.), thereby leaving a large gap between these two sets of specifications.

The impact of the EIF so far appears to have been rather modest, in part because PEGS have not yet appeared in significant numbers. Nevertheless, the EIF is referenced frequently in national interoperability frameworks, most of which at least claim the intention of complying with it. [4] [6] [7] [15]

\section{eGovernment Interoperability Framework of}

United Kingdom

The eGIF is intended to help create interoperable systems working in a seamless and coherent way across the public sector in order to provide better services, tailored to the needs of citizen and business at a lower cost. Its scope includes G2G, G2C, G2B (UK to worldwide) (where "G" stands for "Government" "C" for "Citizens" and "B" for "Business"), UK to EU/USA, etc.

It is one of the most mature national interoperability frameworks: its first version was published in 2001, and it had reached version 6.1 as of March 2005. It specifies the use of SOA as well as providing support, best practice guidance, toolkits, and centrally-agreed schemas (for example, involving XML). [1] [13] [15]

In the United Kingdom, the eGovernment Unit, formerly known as Office of the e-Envoy, has based its technical guidance on the eGovernment Interoperability Framework (eGIF). e-GIF mandates specifications and policies for any cross-agency collaboration and for eGovernment service delivery. It covers four areas: interconnectivity, data integration, eservices access, and content management. The e-GIF contains a Technical Standard Catalogue, which is revised and updated every six months. This framework appears today in a crossroad since it has to grow in scope in order to accommodate the different kinds of technical 
and process standards and adopt a newer, more business needs oriented governance regime. To date, the UK eGIF has focused on standards for interconnection, data integration, content management metadata, eServices access and channels, and standards for specific business areas, yet the interoperability problem remains. What is new now in the UK is the realisation that an open standards 'landscape' is but a foundation for a larger, more holistic requirement, 'the government enterprise architecture' and that more attention needs to be paid on the "process" and the "people" dimensions, ensuring that everything from governance to technical standards selection and mandating is business needs driven and not technology opportunity driven. [3]

The lessons from the UK experience for others embarking on creating an e-GIF are [3]:

- In order to make the leap straight into the enterprise architecture approach, each country's e-government community must have the vision, leadership, managerial and technical capability to meet the real business need through different technologies and to work at a high level of sophistication.

- Policy makers, strategists and implementation planners must be prepared for achieving evolutionary, not revolutionary changes - a small step at a time - and keep in mind that the long haul - quick wins will seem to be small wins in the grand scheme of things. They must not pin their faith for adoption of the eGIF on penalties for non-cooperating, but should impose their will with the help of incentives to the involved organizations.

- The starting position must be well understood and benchmarked so that the gap between the 'as is' and the 'to be' states are well defined. Ongoing monitoring of change needs to be in place in order to know quantitatively what difference the effort has made. Time frames for measurable change need actually to stretch out into years.

- Winning 'hearts and minds' is crucial and mechanisms for increasing awareness must be foreseen. Education schemes to help people 'get with the programme' and become recognised 'eGovernment professionals' are also required.

- The supplier community must be in partnership with the government community, with a shared understanding of the means of delivery and the ends sought.

\section{Standards and Architectures for e-Government} Applications (SAGA)

Germany's Federal Government Co-ordination and Advisory Agency for IT in the Federal Administration, published the Standards and Architectures for eGovernment Applications (SAGA) in February 2003, and updated to version 2.0 in December 2003. SAGA, which stems from the BundOnline 2005 eGovernment initiative launched in September 2000, is guideline that serves as an orientation aid for decision-makers in the eGovernment teams in German administrations. In Standards and Architectures for E-Government Applications (SAGA), the German e-Government Interoperability Framework, moving from taskoriented to process-oriented Administration appears today as the key challenge to overcome. Regarding the current version of the SAGA, the Reference Model of Open Distributed Processing (RM-ODP) is not well used since standards are not appropriately associated to viewpoints and there are many aspects not yet established, e.g. the creation of an XML Data Repository which is currently under way, or not equally addressed, such as the enterprise viewpoint in comparison to the technology viewpoint. Finally, SAGA partially has too much "German / Bund Flavor" and there is not sufficient internationalization at EU level [3].

Further lessons learnt from the experience with SAGA suggest that [3]:

- Standards and technologies to be followed should be proposed in an eGIF, yet a determination on certain technologies is not necessary for achieving interoperability and should not be integrated in eGIFs since variety guarantees continuous innovation and competition and prevents market foreclosure.

- A bottom-up approach needs to be adopted covering equally all the viewpoints of the RM-ODP: technology, information, enterprise, computational and engineering. Creating patterns of standard processes and data models for similar services must be pursued.

- The continuous revises of the eGIF must be balanced between adding the latest developments and experiences (through the discussion in the public eGIF forum) and its being characterized as too complex and overregulated.

\section{Greek e-Government Service Provision and Interoperability Framework}

The vision of the e-Government Service Provision and Interoperability Framework is to facilitate government in adapting to the digital 
era with the introduction of technical policies and specifications for achieving Information and Communication Technology (ICT) systems coherence across the public sector (G2G Government-to-Government) and between the State and citizens (G2C - Government-toCitizens) or businesses (G2B - Government-toBusiness). The new Greek e-Government Service Provision and Interoperability Framework introduces a new system (not a paper-based specification) that will interact with eGovernment portals and back-office applications, guiding their evolution and ensuring interoperability by design, rework or change. The implementation addresses a number of key issues, such as:

- Development of unified governmental data models (in the direction of Core Components).

- Specification of truly interoperable, one-stop governmental services.

- Definition of standards and rules, against which Governmental sites will be constantly measured and certified.

- Adoption of protection, security and authentication mechanisms and arrangement of the corresponding legal issues.

- Change management procedures and customization techniques for applying the findings to the specific Public Administration needs and demands.

The initial application of the Greek eGIF, as well as the evolutions of the German and UK eGIF's are indicating that new perspectives should be taken into consideration from now on, analysed as following:

- Importance and adequate effort should be put in defining standard electronic services for businesses and citizens, thus providing clear examples to administrations and service portal developers.

- The paper-based specification should give way to system-based presentation of the framework, incorporating service descriptions, data definitions, certification schemes and application metrics in a common repository.

- Organisational interoperability issues should be supported by a more concrete methodology of how to transform traditional services to electronic flows.

- The collaboration among European eGovernment Interoperability Frameworks is particularly beneficial for the ongoing Frameworks, since it ensures that lessons from the pioneers' experience are learnt and that the same mistakes will not be repeated.

Future work along the Greek eGIF includes research on the distinct frameworks complementing its first release, publication of XML Schemas based on Core Components methodology, initial training of key staff within administrations and extension of the system in order to encourage stakeholders to engage themselves and build synergies across the public sector in a truly interdisciplinary way. [3]

\section{Comparison of different interoperability frameworks}

The results of different eGIFs are presented bellow comparing them by interoperability dimensions addressed, layers identified, scope and interest groups (see Table 1).

Table 1. Comparison of different interoperability frameworks

\begin{tabular}{|l|l|l|l|l|}
\hline Criteria & \multicolumn{1}{|c|}{ EIF [8] [9] } & \multicolumn{1}{|c|}{ UK eGIF [2] } & \multicolumn{1}{|c|}{ SAGA [12] } & \multicolumn{1}{|c|}{ Greek eGIF [18] } \\
\hline Dimensions & $\begin{array}{l}\text { Organizational } \\
\text { interoperability } \\
\text { Semantic } \\
\text { interoperability } \\
\text { Technical } \\
\text { interoperability } \\
\text { Political context } \\
\text { Legal } \\
\text { interoperability }\end{array}$ & $\begin{array}{l}\text { Only technical } \\
\text { covered }\end{array}$ & $\begin{array}{l}\text { Organizational } \\
\text { interoperability } \\
\text { Semantic } \\
\text { interoperability } \\
\text { Technical } \\
\text { interoperability }\end{array}$ & $\begin{array}{l}\text { Organizational } \\
\text { interoperability } \\
\text { Semantic } \\
\text { interoperability } \\
\text { Technical } \\
\text { interoperability }\end{array}$ \\
& & & \\
& & & \\
& Basic & & \\
& Functions & Public & Interconnectivity \\
Layers & Data integration & $\begin{array}{l}\text { Enterprise } \\
\text { viewpoint } \\
\text { Content }\end{array}$ & $\begin{array}{l}\text { Systems } \\
\text { Computational } \\
\text { Specifications }\end{array}$ \\
\hline
\end{tabular}




\begin{tabular}{|c|c|c|c|c|}
\hline Criteria & EIF [8] [9] & UK eGIF [2] & SAGA [12] & Greek eGIF [18] \\
\hline & $\begin{array}{l}\text { Exchange } \\
\text { Aggregate Services } \\
\text { Administration, } \\
\text { Business, Citizens }\end{array}$ & $\begin{array}{l}\text { management } \\
\text { metadata } \\
\text { eServices access }\end{array}$ & $\begin{array}{l}\text { viewpoint } \\
\text { Technical viewpoint } \\
\text { Engineering } \\
\text { viewpoint } \\
\text { Information } \\
\text { viewpoint }\end{array}$ & Coordination \\
\hline Scope & 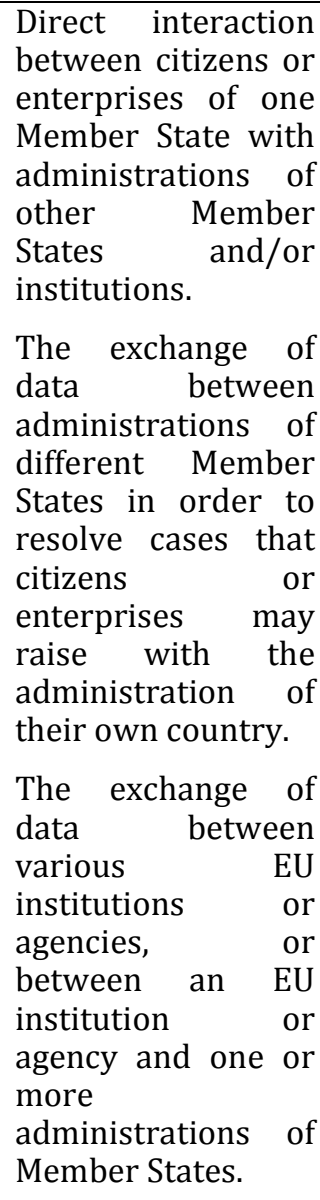 & $\begin{array}{l}\text { The eGIF covers the } \\
\text { exchange of } \\
\text { information } \\
\text { between } \\
\text { government } \\
\text { systems and the } \\
\text { interactions } \\
\text { between: } \\
\text { UK Government and } \\
\text { citizens } \\
\text { UK Government and } \\
\text { intermediaries } \\
\text { UK Government and } \\
\text { businesses } \\
\text { (worldwide) } \\
\text { UK Government } \\
\text { organisations } \\
\text { UK Government and } \\
\text { other governments } \\
\text { (UK/EC, UK/US, } \\
\text { etc.). }\end{array}$ & $\begin{array}{l}\text { There are three } \\
\text { target groups for } \\
\text { the Federal } \\
\text { administration's } \\
\text { services: } \\
\text { Citizens } \\
\text { (Government to } \\
\text { Citizens - G2C) } \\
\text { Companies to } \\
\text { (Government to } \\
\text { Business - G2B) } \\
\text { Administration } \\
\text { (Government th } \\
\text { Government-G2G) } \\
\text { SAGA's scope of } \\
\text { validity covers the } \\
\text { federal and } \\
\text { administration and } \\
\text { software systems } \\
\text { with interfaces } \\
\text { between federal } \\
\text { authorities and } \\
\text { federal-state } \\
\text { and/or municipal } \\
\text { authorities in order } \\
\text { to support the } \\
\text { public services. }\end{array}$ & 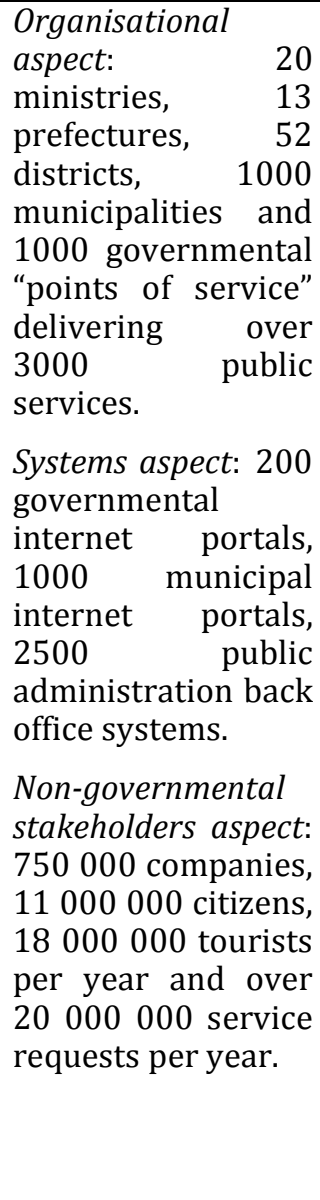 \\
\hline $\begin{array}{l}\text { Interest } \\
\text { groups }\end{array}$ & $\begin{array}{l}\text { Administration } \\
\text { policy makers } \\
\text { responsible for } \\
\text { eGovernment } \\
\text { service } \\
\text { development and } \\
\text { operation, } \\
\text { Administration } \\
\text { officials responsible } \\
\text { for ICT systems } \\
\text { implementation } \\
\text { (and by extension } \\
\text { any contractors } \\
\text { working on their } \\
\text { behalf) }\end{array}$ & $\begin{array}{l}\text { UK government } \\
\text { which includes } \\
\text { central government } \\
\text { departments and } \\
\text { their agencies, local } \\
\text { government, and } \\
\text { the wider public } \\
\text { sector, e.g. non- } \\
\text { departmental } \\
\text { public bodies } \\
\text { (NDPBs) and the } \\
\text { National Health } \\
\text { Service (NHS). }\end{array}$ & $\begin{array}{l}\text { SAGA is primarily } \\
\text { designed for } \\
\text { decision-makers in } \\
\text { the fields of } \\
\text { organization, } \\
\text { information } \\
\text { technology and } \\
\text { eGovernment teams } \\
\text { in German } \\
\text { administrations. }\end{array}$ & $\begin{array}{l}\text { All governmental } \\
\text { institutions in } \\
\text { Greece. }\end{array}$ \\
\hline
\end{tabular}


Interoperability is frequently viewed as having number of distinct dimensions. One of the earliest views of interoperability is the layered or "stack" view of interaction among computer systems over a network. The earliest popular version of this view was the traditional Open Systems Interconnect (OSI) model, here are listed layers identified by eGIFs analyzed. Scope and interested groups views are concerned with the functional range of an IF. Within the broad domain of eGovernment, interoperability may be tasked with a range of different scopes.

\section{Key Interoperability problems in Lithuania}

Taking into consideration the importance of eGovernment interoperability issues the series of interviews were carried out with different stakeholders. The interviews allowed to indentify these key problems of Lithuania eGovernment interoperability:

At the political level:

- There are no support for the use of standards or other legal and good practice documents (e.g. prepared by the IDABC program);

- There no support to promote good practice of interoperability solutions;

- The high decentralization of state registries exist. Strong Register Centralization policy (e.g. transfer of the entire registry to the Registers Center) could be accelerate the interoperability issues.

At the legal level:

- There is no generally accepted the document format for data among organizations (in particular, between government organizations). Every institution use different formats each time;

- Legal requirements from different authorities, in the absence of commonly adopted formats, often intersect;

- The service level agreement is not adopted;

- There is no standard safety specifications, which could be implemented and the system of security-assessment validation.

At the semantic level:

- $\quad$ Each institution use own semantic data exchange requirements, and standardized specification does not exist (such as the XML data should look scheme and the like.);
- Frequently authorities do not have the data for the "semantic menu" (e.g. the possible data sets, the XML data schemes), and every time propose a new combination;

- eDocuments data structure is not defined.

At the technical level:

- There is no common agreement of technical realization;

- There is no standardization of the general requirements for data exchange protocols;

- There is no standardization of the general requirements for security requirements of data exchange.

\section{Conclusions}

After evaluating the best practises across EU countries and opinion of Lithuania governmental institutions, the following recommendations for solving interoperability problems within Lithuania might be provided:

- The lack of political leadership is the main constrain within eGovernment Interoperability issues. The state should appoint the institution which will take leadership in development and implementing eGovernment interoperability framework;

- The eGovernment interoperability framework should address political, organization, semantic and technical dimensions. The framework should be based on 2nd generation approach - to provide not only the specifications and standards, but also built tools for implementing eGIF and ensure coordination mechanism for implementing it;

- The eGIF should provide high level standards (the data, technical, authentication, web portal and multichannel access standards) for systems used in public eService provision;

- The lack of dialogue between state institutions causes serious interoperability problems. The initiation of constructive dialog (e.g. task force for interoperability) and supporting share of current successful solutions will allow facilitation of interoperability issues tackling within the country.

\section{Acknowledgement}

Authors acknowledge Ministry of Interior of the Republic of Lithuania and Lithuania State Science and Studies Foundation for project support. 


\section{References}

[1] Adam Smith Research Trust. Rewiring Democracy: Better e-government for the UK. London: ASI (Research) Ltd. Retrieved June 15, 2008,

from http://www.adamsmith.org/images/uploads/p ublications/egov3_final.pdf

[2] Cabinet Office - e-Government Unit $e$ Government Interoperability Framework, Version $6.1,2005$

[3] Charalabidis Y., Tschichholz M. and Hopkirk A. Advancing the eGovernment Interoperability Framework in European Countries: Architectures, Challenges and Perspectives from the New Greek eGIF. Proceedings of the eChallenges 2007 Conference, BIOS Press, The Hague, p. 134-141.

[4] Malotaux, M., van der Harst, G., Achtsivassilis, J. \& Hahndiek, F. Preparation for Update European Interoperability Framework 2.0: Final report. Gartner, Inc. Retrieved August 11, 2008, from

http://ec.europa.eu/idabc/servlets/Doc?id=291 $\underline{01}$

[5] Guijarro L. Interoperability frameworks and enterprise architectures in e-government initiatives in Europe and the United States, Government Information Quarterly (24: 1), January 2007, pp. 89-101.

[6] IDABC Architecture Guidelines: For TransEuropean Telematics Networks for Administrations, Version. 7.1. Brussels, 2004. Retrieved August 11, 2008, from http://ec.europa.eu/idabc/servlets/Doc?id=192 80

[7] IDABC Architecture Guidelines: For TransEuropean Telematics Networks for Administrations Annexes, Version. 7.1. Brussels, 2004 Retrieved August 11, 2008, from http://ec.europa.eu/idabc/servlets/Doc?id=192 81.

[8] IDABC European Interoperability Framework for pan-European e-Government Services, Version 1.0, Brussels, 2004. Retrieved August 05, 2008, from http://europa.eu.int/idabc/en/document/3761.

[9] IDABC Draft document as basis for EIF 2.0. Brussels, 2008. Retrieved September 11, 2008, from http://ec.europa.eu/idabc.

[10] Institute of Electrical and Electronics Engineers. IEEE Standard Computer Dictionary:
A Compilation of IEEE Standard Computer Glossaries. New York, 1990.

[11] Janssen M. and Scholl, H. J. J. Interoperability for electronic governance, Proceedings of the 1st international conference on Theory and practice of electronic governance. 2007, pp. 45-48.

[12] KBSt unit at the Federal Ministry of the Interior SAGA: Standards and Architectures for eGovernment Applications Version 3.0, 2006.

[13] Maslen, J. What's eGIF got to do with it? Retrieved August 21, 2008, from http://www.accessmylibrary.com/comsite5/bi n/pdinventory.pl?pdlanding $=1$ \& referid $=2930 \&$ purchase_type=ITM\&item_id=0286-3889812.

[14] Müller, M. eGovernment, Interoperability and Innovation, Proceedings of the eChallenges 2006 Conference, BIOS Press, The Hague, 2006, pp. 68-74.

[15] Rothenberg, J., Botterman, M. and van Oranje-Nassau, C. Towards a Dutch Interoperability Framework: Recommendations to the Forum Standaardisatie. RAND Corporation, 2008.

[16] Tambouris, E., Tarabanis, K., Peristeras, V. and Liotas, N. Study on Interoperability at Local and Regional Level, Technical report, Modinis Lot 2, 2007.

[17] Scholl, H. J. J. Interoperability in eGovernment: More than Just Smart Middleware. Proceedings of the 38th Annual Hawaii International Conference on System Sciences (HICSS38), 2005.

[18] The Greek eGIF Website. Retrieved August 21, 2008, from http://egif.epu.ntua.gr.

[19] The Greek Digital Strategy 2006-2013, Athens, 2007. Retrieved August 21, 2008, from http://www.infosoc.gr/infosoc/en-

UK/sthnellada/committee/default1/top.htm

[20] Vitkauskaite, E. and Gatautis R. eGovernment interoperability issues in Lithuania. ICEB-2008: proceeding of the Eight International Conference on Electronic Business "Enriching Global Business practices", Hong Kong. 2008, pp. 80-87.

[21] Zhao, J. L. and Cheng, H. K. Web services and process management: a union of convenience or a new area of research?. Decision Support Systems, Issue 40, 2007, pp. 1-8. 